\title{
QR Codes in Education
}

\author{
Ching-yin Law \\ Simon So \\ Hong Kong Institute of Education
}

\begin{abstract}
Q R$ codes, developed by a Japanese company, have been around for over fifteen years. With the advent of smart and Web capable mobile devices, we witness a steady growth of interesting commercial applications using $Q R$ codes. As the movement of using $Q R$ codes in education is still in its infancy, this paper serves to be one of the first comprehensive papers in journal publication to fully delineate (a) the user characteristics of $Q R$ codes, (b) the processes of making and reading $Q R$ codes, (c) the survey of commercial applications using $Q R$ codes, (d) the literature review of educational applications using $Q R$ codes, and (e) offer suggestions and implementations of $Q R$ codes in school education.
\end{abstract}

Keywords: Quick Response (QR) Code, 2D Bar Code, Mobile Learning

\section{Introduction}

Quick Response (QR) codes are versatile. A piece of long multilingual text, a linked URL, an automated SMS message, a business card or just about any information can be embedded into the two-dimensional barcode. Coupled with moderate equipped mobile devices, QR Codes can connect the users to the information quickly and easily. In this paper, we explore how QR codes can be used in education. The low technical barrier of creating and reading QR codes allows innovative educators to incorporate them into their educational endeavors. The operations to retrieve or store QR codes are incredibly simple and quick, and with mobile devices, make them the ideal educational tools for teaching and learning. This paper is organized as follows. We will first introduce the user characteristics of QR codes in Section 2. This overview highlights the superiority of QR codes over other one dimensional or two dimensional barcodes. In Section 3, we provide examples of applying QR codes in commercial settings. Particularly in Japan, QR codes are everywhere and most people have mobile phones equipped with QR code readers. In Section 4, we conduct literature review on the existing educational applications with QR codes by searching the Internet and major research publication venues. Although QR codes existed for over fifteen years, there are not so many research applications in this area. However, we witness the interest to this technology is increasing in education. This is partly due to the fact that camera-equipped and software-downloadable mobile phones are surging in recent years. In Section 5, we introduce to the readers how to prepare and read a document with QR codes. Our suggestions and implementations of QR codes in school education are then provided 
in Section 6. We carried out the experiment in two primary schools. Students' responses to the exercises described in Section 6 are captured in Section 7. In Section 8, we conclude the paper with some reflective remarks.

\section{Understanding QR Codes}

QR Code is a form of 2D bar codes. A sample is shown in Figure 1. It was developed by Denso-Wave, a Japanese automatic data capture equipment company (Denso, 2009), in 1994. "QR" stands for "Quick Response." It is readable by moderately equipped mobile phones with cameras and QR scanners. Information such as URL, SMS, contact information and plain text can be embedded into the two dimensional matrix. With smart phones, we can visit the Website linked by the URL quickly, we can send the SMS message directly or we can save the contact information onto the address book easily. This format of 2D bar codes is so popular in Japan and emerges gradually around the world because (a) the patent right owned by Denso Wave is not exercised (Denso, 2010a), (b) its specification is disclosed to the public by the company so as the specifications, ISO/IEC 18004:2000\&2006 (International Organization for Standardization) and JIS X 0510 (Japanese Industrial Standards), can be formed (ISO, 2010; JISC, 2010), and (c) it has a large data capacity in a small printout size and high speed scan utilities via mobile devices are readily available.

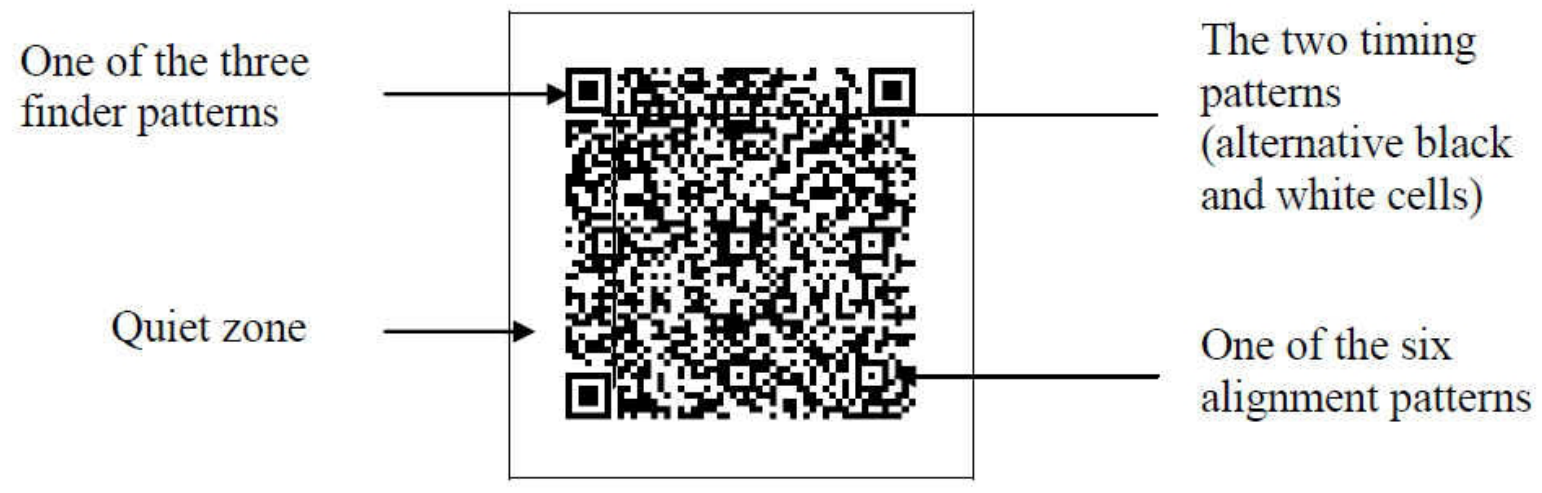

Figure 1. A QR code sample

A QR code is capable of holding 7,089 numeric characters, 4,296 alphanumeric characters, 2,953 binary bytes, 1,817 Kanji characters or a mixture of them. The data capacity is much higher than other 2D codes such as PDF417, DataMatrix and Maxi Code (Denso, 2010b). It stores information in both vertical and horizontal directions. A QR code can be read from any direction in $360^{\circ}$ through position detection patterns located at the three corners as shown in Figure 1. A QR code can be read even it is somewhat distorted by either being tilted or on a curved surface by alignment patterns and timing patterns. The error correction capability against dirt and damage can be up to $30 \%$. A linking functionality is possible for a QR code to be represented by up to $16 \mathrm{QR}$ codes at maximum so that a small printing space is possible. The size of a $\mathrm{QR}$ code can vary from $21 \times 21$ cells to $177 \times 177$ cells by 4 cell-increments in both horizontal and vertical direction.

Data can be easily encrypted in a QR code to provide a confidentiality of information embedded in the code. It can also handle various languages. For examples, there are a number of standards adopted by Asian countries like GB/T 
18284 by Chinese National Standard in 2000, KS-X ISO/IEC 18004 by Korean National Standard in 2002, and TCVN7322 by Vietnam National Standard in 2003.

\section{Using QR Codes in Business and Industry Applications}

Many examples of applying QR codes in business and industry can be found in Australia, China, Hong Kong, Japan, Korea, Singapore and Taiwan (ITSC, 2008) as illustrated below (see also Figure 2):

- Blood test process management in Australia

- LPG cylinder bottle management in
Australia

- Tracing of livestock with ID numbers in Australia

- Jewellery certification system in China

- Bus commuters pass issuing system in Japan

- Sushi freshness control system in Japan

- Betting ticket management in Japan

- Passenger management for a casino cruiser in Japan

- Patient identification in Japan, Hong Kong and Singapore

- Application in agriculture in Taiwan

- Telecom company as a basis of ebusiness in Taiwan

- Payment slips management in Taiwan
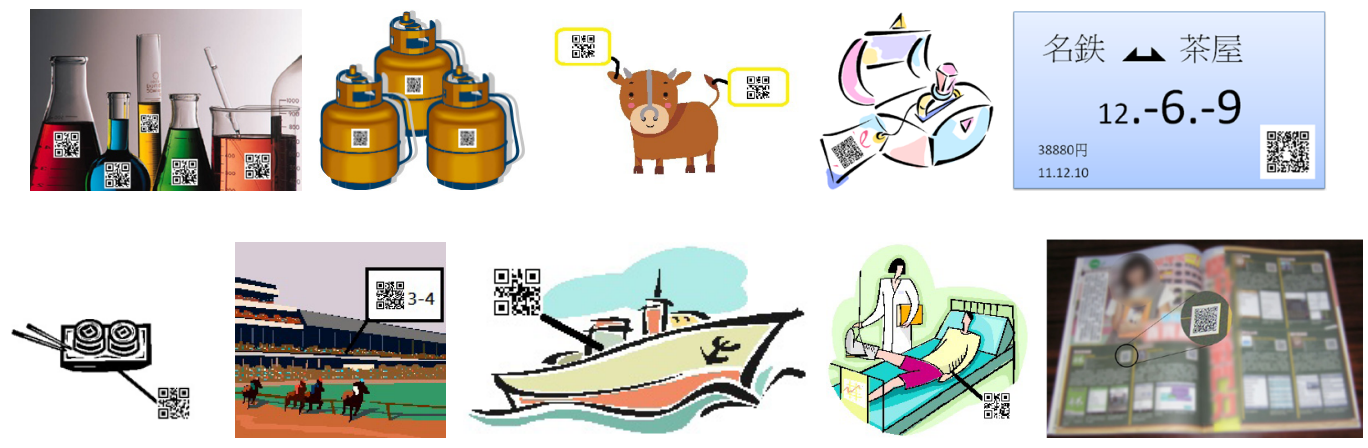

Figure 2. Examples mentioned by Information Technology Standards Committee Singapore (The original illustrations can be found in http://www.itsc.org.sg/pdf/synthesis08/Three_QR_Code.pdf)

\section{Using QR Codes in Education}

The study of QR codes in education can be placed in the context of mobile learning. Mobile learning is a major field of research in education (Kukulska-Hulme, 2005; Naismith et al., 2005; Pachler, 2010; Sharples, 2007). Before we go on to provide the literature review of QR codes in education, we would like to highlight the salient characteristics of mobile learning and guide the readers to understand our motive behind this research.

The trinity of "location independence," "time independence" and "meaningful content" is the most important aspect in the study of mobile learning (So, 2008). These three dimensions are the salient characteristics of mobile learning and distinguish from the related fields of e-learning or Web-based learning. "Location independence" refers to learning not restricted to a fixed location. Locations include indoor and outdoor settings. "Time independence" means that learning may extend beyond the discrete classroom learning time, but into other informal learning environment at suitable time. We refrain from using the phrase, "anyplace and anytime," a slogan commonly used in mobile learning. This is because the phrase is over simplification and somewhat 
propagandistic. "Meaningful content" refers to the content not only at the semantic level. We need to consider whether the content is suitable to be delivered with the media, devices and communication settings as well.

\section{Examples of applying $Q R$ codes in Education}

The movement of using QR codes in education is still in its infancy. We have only a few examples which can be drawn from the literature as described below:

- The University of Bath is the forerunner of applying QR codes in education. Some educational applications using QR codes are reported in the following:

1. For each catalogue search at the library of the University, a QR code will also be displayed automatically to summarize the key information, the title, the author, and the shelf location as shown in Figure 3.

2. Student assignment submission to the Faculty of Engineering \& Design needs to accompany with a coversheet bearing the relevant $\mathrm{QR}$ code as shown in Figure 4.
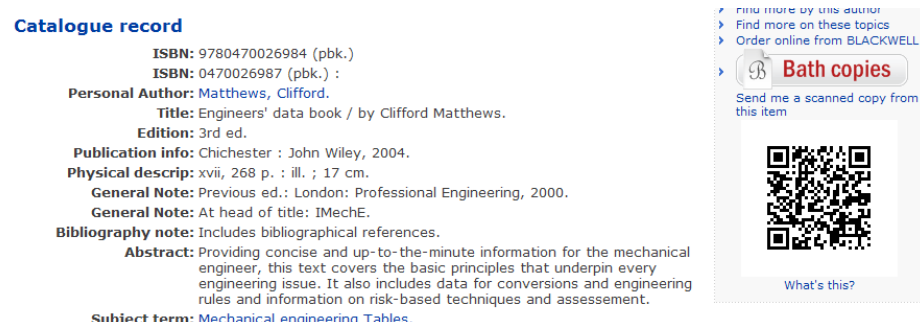

Figure 3. A catalogue sample from the library of the University of Bath (Source: http://library.bath.ac.uk/uhtbin/bath/UB-LIBS/ckey/1678947)

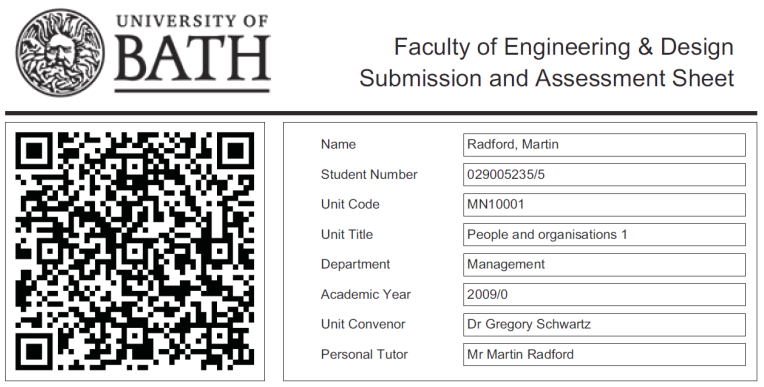

Figure 4. A student assignment submission sheet from the University of Bath (Source: http://www.bath.ac.uk/barcodes/p/?a=5745507800,MN6555675545AY,A,56,MN65556A) 


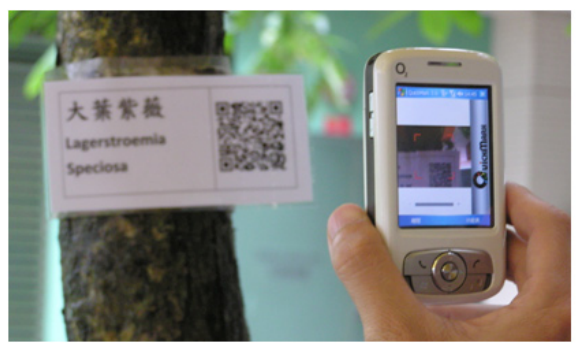

Scan the QR code on the tree

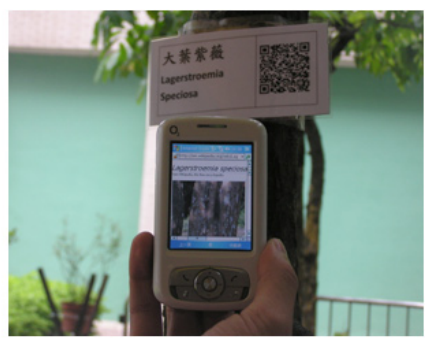

Link to the resource

Figure 5. Students can explore life science subjects through QR codes

3. QR codes are automatically added to the bottom of Moodle print-outs. The QR code contains the URL of the page on that particular Moodle course.

4. QR codes can also be found on posters around campus, on Websites and service blogs for bookmarking, in handbooks linking to activities, and in marketing materials from departments.

- Huang et. al. (2008) integrated Pocket PCs and QR codes to provide a ubiquitous learning environment for primary students to explore life science subjects such as trees similar to Figure 5. The authors conducted a pre-test and post-test study with two groups of students (i.e., control and experiment groups) to find out the effectiveness for the described ubiquitous learning environment.

- A similar approach of realizing the ubiquitous STS collaborative learning environment with QR codes was reported by Chao (2007).

- Chiang et. al. (2007) developed an information platform to provide students and staff the channels to share the learning resources and information. An outline of the system is shown in Figure 6. Windows Mobile device emulations were shown in the paper by Chiang.
- Liu, Tan and Chu (2007) constructed a QR code and handheld augmented reality supported learning system to improve students' English level as shown in Figure 7.

- A student designed a QR-code periodic table of chemical elements in Italy as shown in Figure 8 (Rizzo, 2009).

- Chen et. al. (2008) reported that they integrated QR codes with the Opensource Opencourseware Prototype System (OOPS) in Taiwan. MIT OpenCourseWare (OCW) has formally partnered with this organization to translate MIT OCW courses into Traditional Chinese.

- A mobile phone application system with QR codes for classroom management, communication and evaluation was reported by Chaisatien and Akahori (2006).

- A formative class assessment using questionnaires and shuttle card called "Daifuku-cho" with mobile phones and QR codes in Japan (Susono \& Shimomura, 2006). 


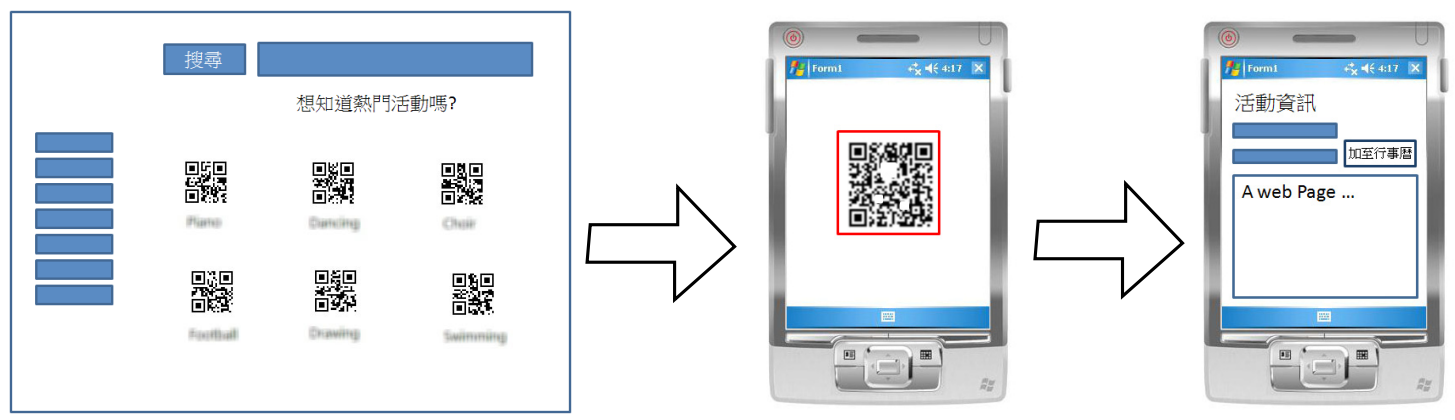

Figure 6. An information platform for information sharing

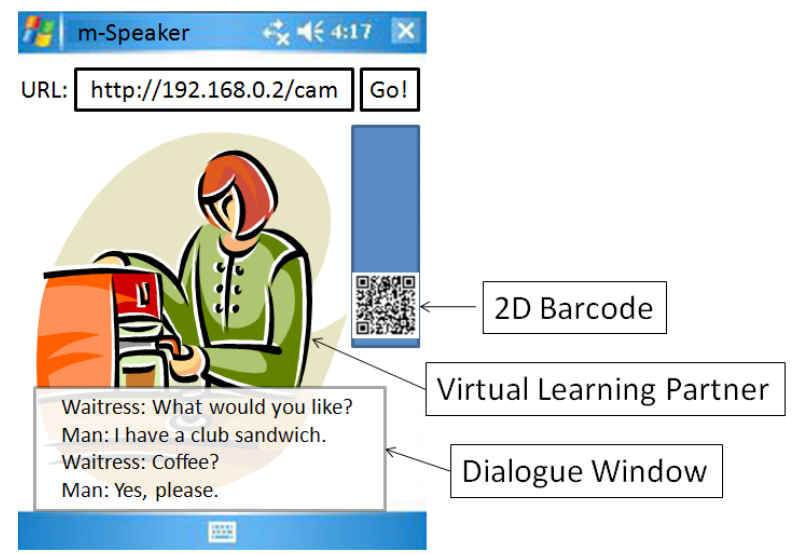

Figure 7. English learning with support of QR codes

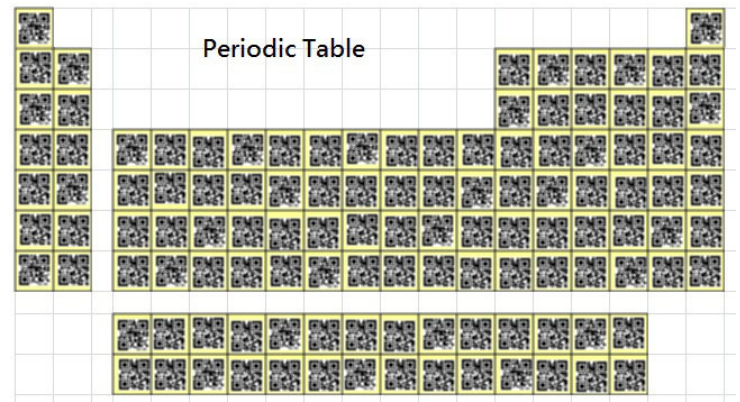

Figure 8. The layout of a periodic table with QR codes

(The original illustration could be found in http://www.qrcode.es/?p=350\&language=en) 
5. Processes of Preparing and Reading a Document with QR Codes

To prepare a document embedded with QR codes, the simplest way to do is to generate the specific codes using some of the tools available from the Internet. These images can then be embedded into the document at the appropriate places. If the mobile device does not build in any QR code reader, the user needs to download the right decoder from the Internet and installs it on to the device. The following steps illustrate the processes.

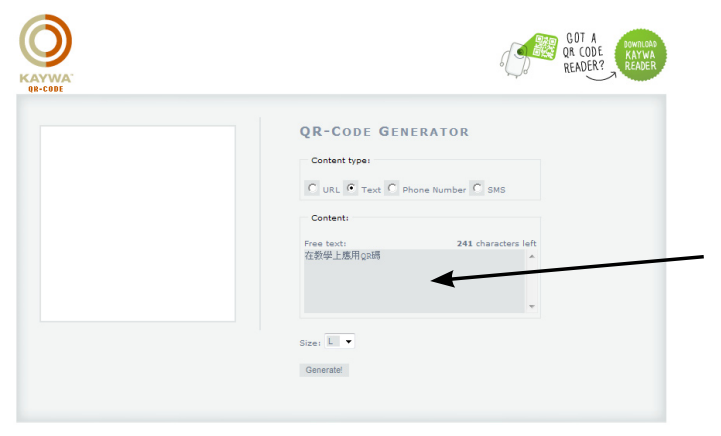

Text (in Chinese): Applying QR Codes in Learning and Teaching

Figure 9. Generating a QR code with a specific text

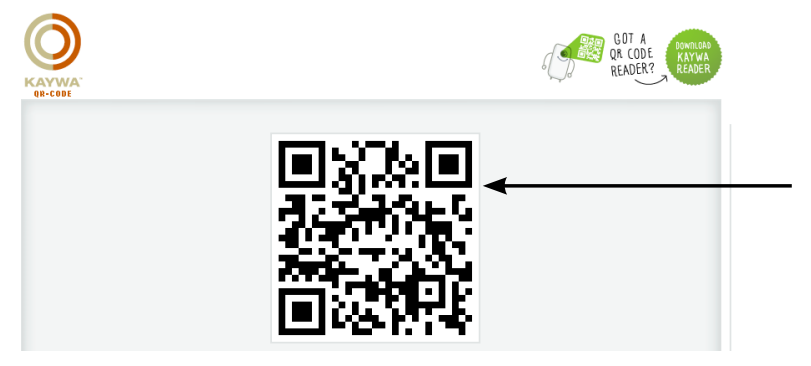

Save this image file...

Figure 10. Save the QR code image 
Step 2: The Website will generate the $\mathrm{QR}$ code for you as shown above.

Step 3: We can save the generated image file and embed it into wherever we want in the document.

Step 4: We need to load the mobile device with the right decoder. You can find many application Websites supplied the decoders for different mobile devices. These include:

- i-nigma: http://www.i-nigma.com/ Downloadi-nigmaReader.html

- Quickmark:http://www.quickmark. com.tw/En/basic/download.asp

Step 5: We need to install the application into the device. An example with Kaywa:

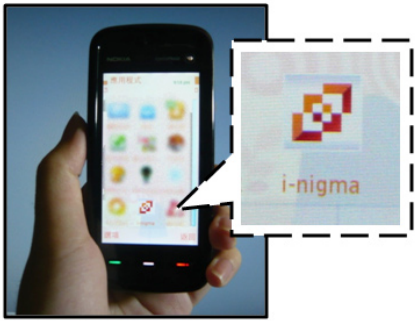

Figure 11. Install the reader on to the mobile phone

Step 6: For the document with the embedded image, the user can just slide the decoder over the area and the text will automatically be displayed as shown below. If the text is an URL, you can just click the link and the reader will take you to the Website. If the text is a contact record, the reader can save the record to the address book of the phone with just one click.
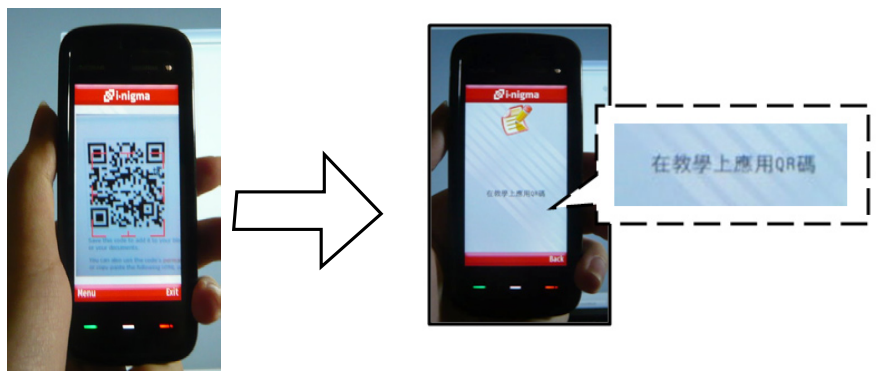

Figure 12. Slide the device over the QR code and the message will display instantly

\section{OurSuggestionsand Implementations of QR Codes in School Education}

In Section 4, we provided some examples from the literature to illustrate how QR codes can be used in education. Innovative educators can harness the great possibilities of this technology that can offer. In this section, we will explore three broad areas in which QR codes can potentially offer great opportunities for educators to explore with. They are (1) Math
Trail in the area of outdoor learning activities, (2) English Listening Exercise in the area of self-directed multimedia learning activities, and (3) Self-evaluation Exercise in the area of self-assessed tasks.

\section{Math Trail}

Many of K-12 mathematics teachers have used and expanded on the math trail concept (NMT, 2010). According to the Presidential Award winner Kay Toliver from New York, 
the concept was first developed by Australian educator Dudley Blane. Interested readers are recommended to look into the rationale for organizing such meaningful activities and to see why the math trail concept is popular in many countries. In a math trail activity, students explore their communities and create one or more math problems that relate to what they find. The activity generally is carried with a group of students. A math trail activity can be expanded and organized in the form of collaboration or competition among students. In our experiment with the aid of QR codes, we made it to be an individual activity. We carried

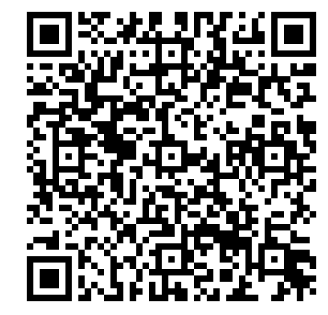

（a）例子: 現有 10 個蘋果, 媽媽吃了2個, 餘下多 少個？下一個目的地 - XXX 課室門外 (We have 10 apples. Mother ate 2 apples. How many apples remain? The next location is $\mathrm{RM}: \mathrm{XXX}$ ) out the activity with a number of young students individually from a local primary school. Prior to the math trail activity, we arranged each student to learn the basic operations of a mobile phone loaded with a QR code reader by practicing the example shown in Figure 13(a). For each location, the student needs to answer a question by scanning the code and write down the answer. The student has to write down the answer onto the worksheet. Figure 13(b) illustrates the QR code for the $5^{\text {th }}$ question. The activity of a student is shown in Figure 14 with his worksheet in Figure 15.

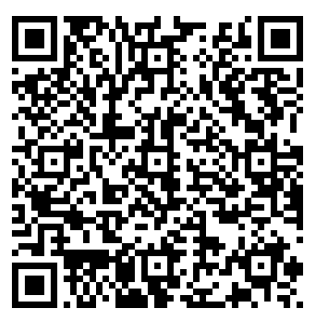

(b) 問題5: 列出 3 和 5 的首 5 個公倍數。下一個目的 地 - 602 課室, 將所有物資交回給老師(List out the first five common multiples of 3 and 5. The next location is RM: 602 . Return all materials to the teacher.)

Figure 13. (a) An example and (b) the $5^{\text {th }}$ question of the math trail activity

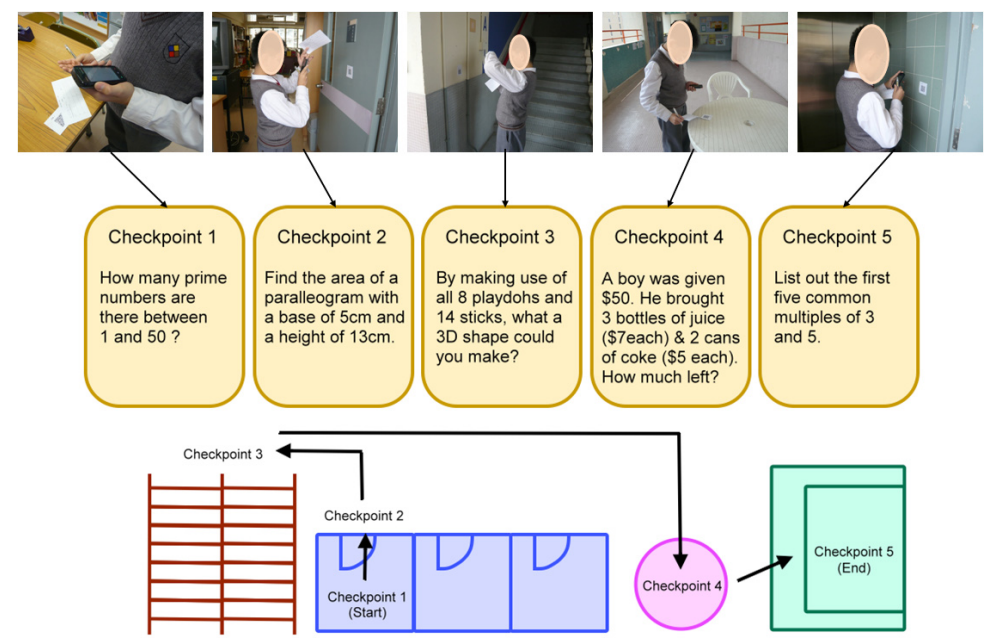

Figure 14. The math trail activity of a student 


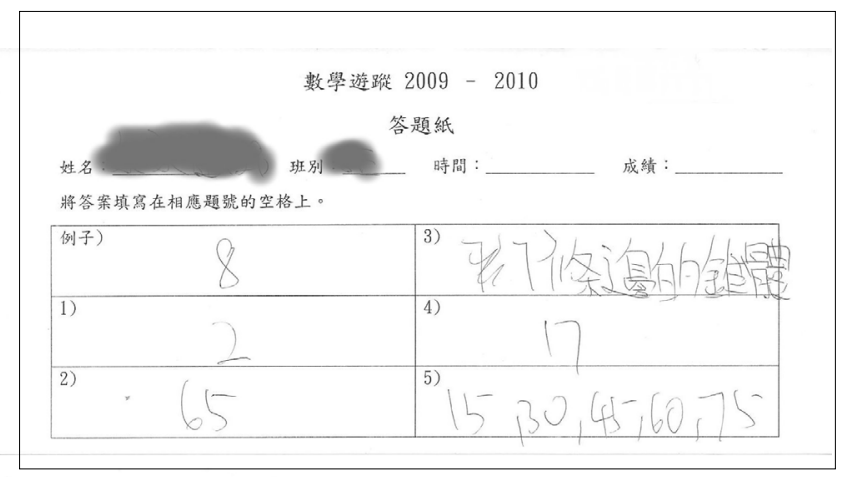

Figure 15. The worksheet was prepared by the student in Figure 14

Beside the above math trail activity, we can organize other similar activities such as Science Trail, Treasure Hunt or other outdoor activities (Osawa, et. al., 2007). QR codes can be very useful in these educational activities.

\section{Listening Exercise}

Listening exercises are essential to language learning. Teachers regularly conduct listening lessons in class. Supplementary exercises in CD or DVD from publishers or commercial production houses are commonly used. These exercises may not be flexible enough to cater for the diverse needs of the teachers. Also, the listening text must be pitched at the right level of difficulty. Teachers are the best persons to select the appropriate listening comprehension for the students. Furthermore, a complete recall for a long piece of aural text is a poor expectation and hence not recommended. With all these issues in mind, worksheets with QR codes linked to Websites for direct audio playback can be a low cost and flexible solution to language learning. In this experiment, we demonstrate how we can approach these activities with QR codes.

First, teachers prepare the audio materials either by editing from existing sources or recording their own materials. If the audio material is a long one, we can break it into pieces. Alternatively, we can anchor into the corresponding positions of the audio material by the appropriate QR codes. Second, we prepare the worksheet similar to the previous exercise. The corresponding QR codes with clear instructions should be placed onto the worksheet. The QR codes link directly to the Web-based audio depository prepared by the teachers. With just a quick scanning action and a click, the learner can listen to the right piece of audio material. Last, a pre-listening activity should be administrated to prepare the student for this type of exercise. Figure 16 shows the listening activity of three students. The worksheet carried out by one of the students can be found in Figure 17(a) against the transcript of the aural text in Figure 17(b) on the next page.

By linking the $\mathrm{QR}$ codes on a paper-based task to the multimedia resources deposited on the Web with just two simple operations provide a very efficient and flexible way for the students to obtain the resources ubiquitously. The resources could be video clips, news clips or simply a Web page. We believe that the possibility of applying QR codes for teaching and learning in this way is unlimited. 


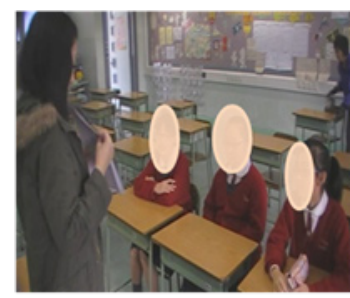

The teacher explained the worksheet.

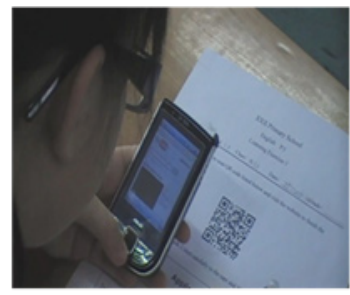

A student snipped the QR code on the worksheet.

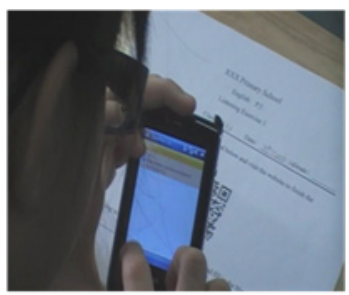

The phone converted it into a URL to be clicked

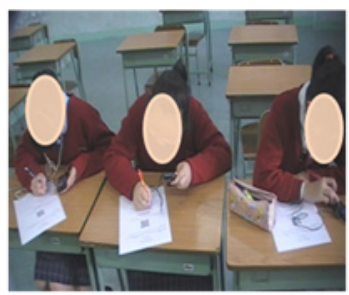

The students carried out the listening exercise.

Figure 16. The listening activity using QR codes

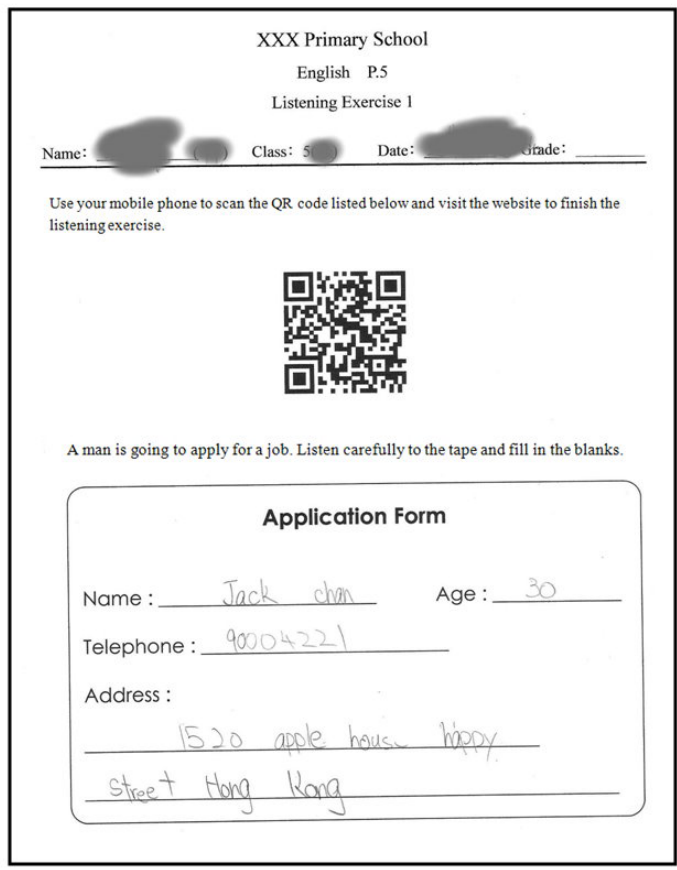

(a)

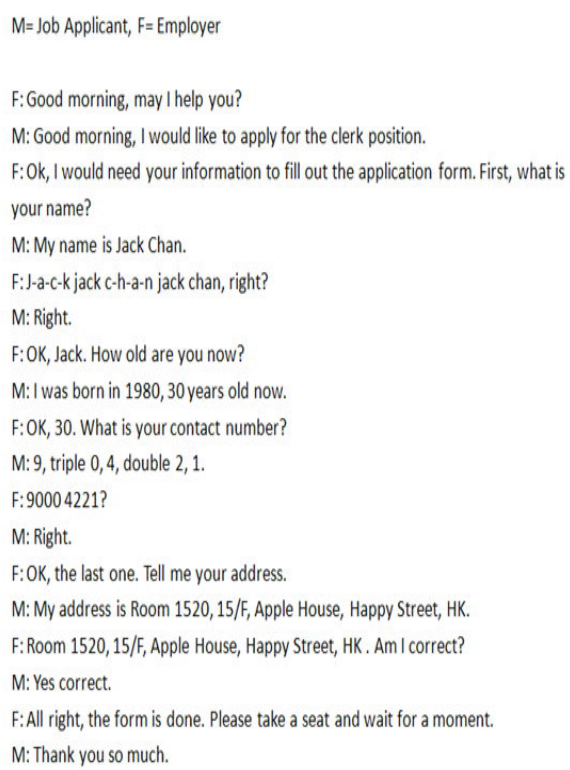

(b)

Figure 17. (a) The worksheet of a student, (b) The transcript of the exercise

\section{Self-Evaluation Exercise}

Students' engagement by way of evaluating their own work is a good strategy to motivate students. Students can step back to think about their learning and make correction or adjustment to their knowledge and concept on certain topics. Students learn how to learn, able to reflect on and monitor their learning progress are of paramount importance to their learning. Self-assessment builds meta-cognition as it involves students in understanding the standards expected of them, in setting and monitoring their own learning goals, and in developing strategies for working towards achieving them. Furthermore, this approach helps to release the teachers from marking so many assignments and tasks. Similar to the listening exercise, the worksheet carried out by one of the students can be found in Figure 18(a). The simple Web platform in which the students could check their answers is depicted in Figure 18(b). In fact, the QR code printed on this worksheet 
was directly linked to a simple Web page showing the answers. For some applications, we could encode the answers straight into the QR code itself if the text is less than two thousand characters approximately. Moreover, we could use multiple QR codes to guide the learners through the self-assessment process. A trace of the process in terms of time and accuracy can be examined after the activity is completed.

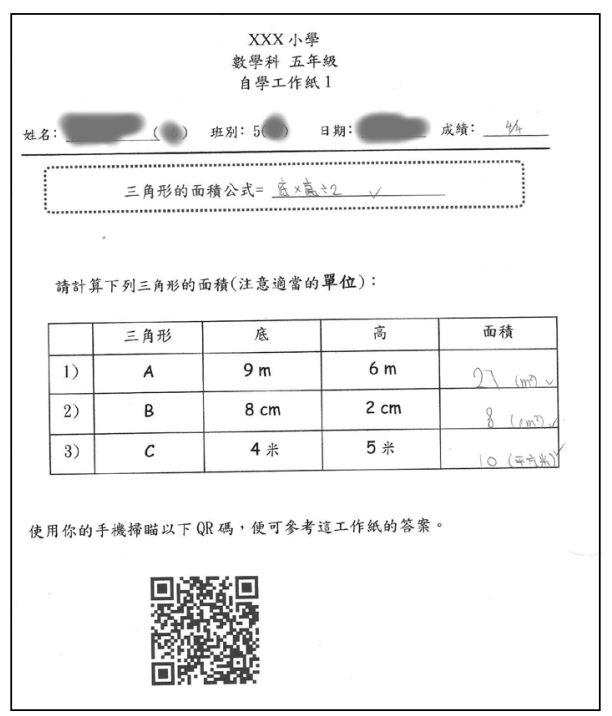

(a)

\section{Students' Responses to the Exercises}

We conducted interviews after each exercise as described in Section 6. The following interviews with some of the students revealed their opinions about using QR codes in school education. These interviews were conducted separately in Cantonese. The conversations have not been edited and represented as the original transcript.

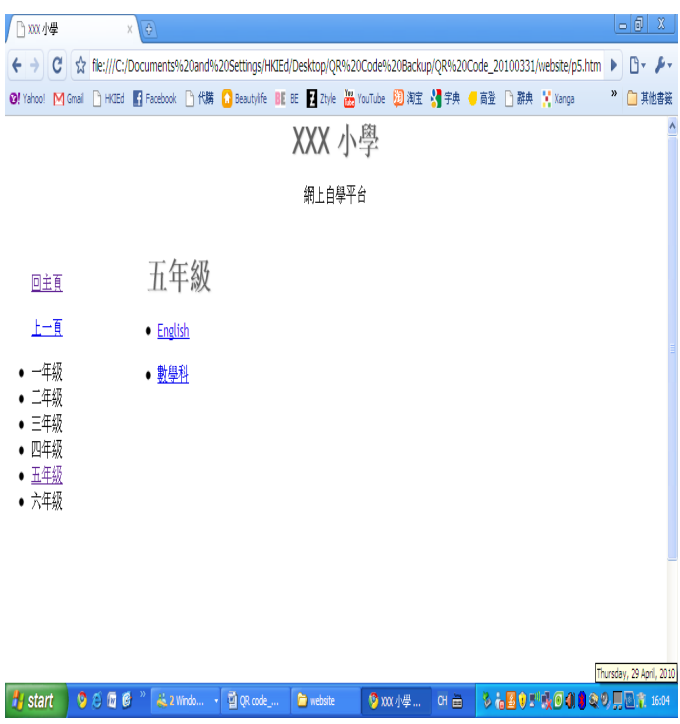

(b)

Figure 18. (a) The worksheet of a student, (b) A Web platform to assess the answers

Math Trail

\begin{tabular}{|c|c|}
\hline Dialogue & Translation \\
\hline 筆: 對於手機操作，易於用嗎？ & Interviewer: Is the mobile device easy to use? \\
\hline $\begin{array}{l}\text { 甲 : 好易。 } \\
\text { 乙: 唔難用。 } \\
\text { 丙: 未試過, (手機操作) 難 (用), 去到圓檯果度 } \\
\text { 整極都整 (瞄準) 唔到。 }\end{array}$ & $\begin{array}{l}\text { A: Easy. } \\
\text { B: Not difficult. } \\
\text { C: Not tried before. Difficult. When I was snapping at } \\
\text { the round table, I could not properly target it. }\end{array}$ \\
\hline
\end{tabular}




\begin{tabular}{|c|c|}
\hline Dialogue & Translation \\
\hline 筆: 對於今次數學遊蹤有什麼感受? & Interviewer: How do you feel about this math trail? \\
\hline $\begin{array}{l}\text { 甲：好好玩, 好新奇。電話 (指手機) 界你做用 } \\
\text { 具。過程好暢順。之前果個無QR碼同埋電 } \\
\text { 話, 但而家有好方便。 } \\
\text { 乙: 好麻煩, 好好玩。好玩就係未試過。所有 } \\
\text { 未試過既野都覺得好玩。麻煩就係煩在對 } \\
\text { 準個位, 甘人地睇一睇到條題目就可以 } \\
\text { 做, 甘又要睇埋果個位味好晒時間。 } \\
\text { 丙：開心。好難對準, 要對準先可以做到。 }\end{array}$ & $\begin{array}{l}\text { A: Quite fun. Quite novel. Given the phone as the tool, } \\
\text { the progress was very smooth. Previous math trail } \\
\text { activities do not have QR codes and phones, it is } \\
\text { now very convenient. } \\
\text { B: Quite troublesome, but quite fun. It was fun because } \\
\text { we have not tried this before. Troublesome to } \\
\text { target. Can be time consuming. } \\
\text { C: Feel happy. Difficult to target. Need to target it } \\
\text { well. }\end{array}$ \\
\hline
\end{tabular}

\section{Listening Exercise}

\begin{tabular}{|l|l|}
\hline \multicolumn{1}{|c|}{ Dialogue } & \multicolumn{1}{|c|}{ Translation } \\
\hline 筆: 對於手機操作, 易於用嗎? & Interviewer: Is the mobile device easy to use? \\
\hline 丁 : 唔難。 & D: Not difficult. \\
戊 $:$ 唔難。 & E: Not difficult. \\
己: 唔難 & F: Not difficult. \\
\hline
\end{tabular}

\begin{tabular}{|c|c|}
\hline Dialogue & Translation \\
\hline $\begin{array}{l}\text { 筆: 如要選擇用哪一個模式進行個人的聆㯖練 } \\
\text { 習, 選擇以往模式 (使用電腦或錄音機) 或 } \\
\text { 手機播放? }\end{array}$ & $\begin{array}{l}\text { Interviewer: If you can choose mobile devices or } \\
\text { previous methods like computers or recorders to carry } \\
\text { out listening exercises, what will you choose? }\end{array}$ \\
\hline $\begin{aligned} \text { 丁: 我會揀番手機, 個人練習用電腦既話比較 } \\
\text { 唔方便。 } \\
\text { 戊 : 用錄音機, 大聲啲。(筆 : 如果只係個人做 } \\
\text { 份聆聽練習, 你都係要用錄音機既聲量先 } \\
\text { 聽到?) 係。 } \\
\text { 己 : 手機, 因爲方便啲。 }\end{aligned}$ & $\begin{array}{l}\text { D: I will choose mobile devices. Inconvenience to use } \\
\text { computers for individual exercises. } \\
\text { E: I will use recorders, louder. (Interviewer: do you } \\
\text { need a recorder's audio volume for individual } \\
\text { exercises). Yes. } \\
\text { F: Mobile devices because they are more convenient. }\end{array}$ \\
\hline
\end{tabular}

Self-Evaluation Exercise

\begin{tabular}{|c|c|}
\hline Dialogue & Translation \\
\hline 筆: 妳對於自學練習的看法？ & Interviewer: Is the mobile device easy to use? \\
\hline 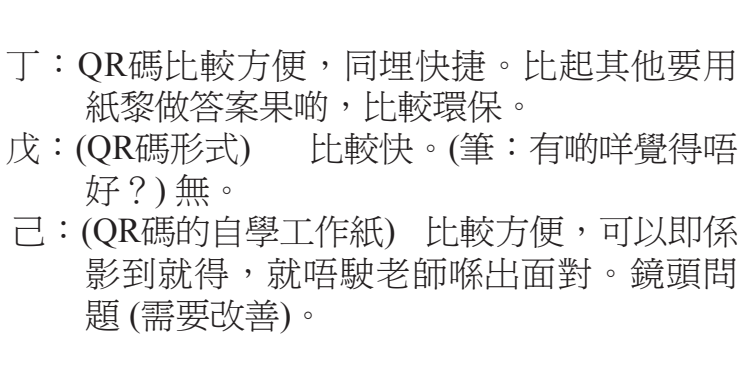 & $\begin{array}{l}\text { D: QR codes are more convenient and quick. Compare } \\
\text { to paper-based answer sheets, this is more } \\
\text { environmental friendly. } \\
\text { E: (The QR code approach is) Quicker. (Interviewer: } \\
\text { anything bad about this approach?) Nil. } \\
\text { F: (Worksheets using QR codes) More convenient. } \\
\text { Instantly can see, no need for the teacher out there } \\
\text { to check our answers. Camera problems (need to } \\
\text { improve). }\end{array}$ \\
\hline
\end{tabular}




\begin{tabular}{|c|c|}
\hline Dialogue & Translation \\
\hline $\begin{array}{l}\text { 筆: 如要妳可以選擇工作紙, 以往工作紙還是這 } \\
\text { 類自學工作紙? }\end{array}$ & $\begin{array}{l}\text { Interviewer: Do you prefer the conventional worksheet } \\
\text { or handheld-assisted worksheet like this? }\end{array}$ \\
\hline $\begin{array}{l}\text { 丁: 我會用手機, 因爲比較快捷, 同埋可以方 } \\
\text { 便啲。 } \\
\text { 戊 : 用手機, 比較快。 } \\
\text { 己 : 都係以往做法, 因爲比較方便, 方便是可 } \\
\text { 以即刻對到答案, 唔駛拍攝。 (筆: 即係 } \\
\text { 對到, 但係你要有老師在場, 先可以即刻 } \\
\text { 對到答案。甘如果老師唔在場, 喺屋企做 } \\
\text { 既時候?) 但係係屋企做就唔會對答案。( } \\
\text { 筆 : 你無對答案既做法? ) 係。 }\end{array}$ & $\begin{array}{l}\text { D: I will use handheld-assisted one. It is relatively } \\
\text { quicker and also more convenient. } \\
\text { E: Handheld-assisted one. Much quicker. } \\
\text { F: I prefer the conventional worksheet, can check } \\
\text { immediately. I don't have to scan with a camera. } \\
\text { (Interviewer: But you need a teacher in the room to } \\
\text { check your answers. If the teacher is not here, like } \\
\text { at home?) But if I work at home, I will not check } \\
\text { my answers. (Interviewer: You do not often check } \\
\text { your answers at home. Right?) Yes. }\end{array}$ \\
\hline
\end{tabular}

\section{Conclusive Remarks}

In this paper, we provided a holistic view of using QR codes in industry and in education. We demonstrated three broad areas to apply QR codes in school education. Overall, the students participated in the experiment found that the activities were interesting. Naturally, the students at this age group were very curious about these new approaches to their otherwise routine exercises. But with this age group, we have additional concerns. First, we must categorically prepare enough mobile devices for the activities. We definitely cannot expect students at the junior levels to carry the right mobile devices to schools. For exercises conducted individually like our Mail Trail, the problem is not acute. However, the cost would be prohibitive for a large group of participants. Second, despite it is quite easy to operate a mobile device equipped with a $\mathrm{QR}$ code reader, we noticed some students highly tilted the devices when they snapped the codes. Students at this age group need to be trained properly. Third, if the mobile devices are equipped with Wi-Fi access and the activities do have the wireless coverage, the cost for communication would be minimal. Otherwise, we may need to rely on $2 \mathrm{G} / 3 \mathrm{G}$ communication provided by mobile carriers. This option can be very expensive.
In general, we believe that $\mathrm{QR}$ codes have great potential in education. Some possibilities are demonstrated in this paper and there are many creative ideas waiting for us to explore. Also, this paper can be served as the first step for the readers to investigate this exciting topic of mobile learning.

\section{References}

Chaisatien, P., \& Akahori, K. (2007). Demonstration of an Application on 3G Mobile Phone and Two Dimension Barcode in Classroom Communication Support System. In C. Montgomerie \& J. Seale (Eds.), Proceedings of World Conference on Educational Multimedia, Hypermedia and Telecommunications 2007 (pp 3330-3336). Chesapeake, VA:AACE (EDMEDIA 2007)

Denso (2010a). QR Code Standardization. Retrieved June 21, 2010, from http://www. denso-wave.com/qrcode/qrstandard-e.html Denso (2010b). About 2D Code. Retrieved June 21, 2010, from http://www.densowave.com/qrcode/aboutqr-e.html

Denso (2009). Denso Wave Incorporated. Retrieved June 21, 2010, from http://www. denso-wave.com/en/index.html

Elena (2009). Educational Qrcodes. Retrieved 
June 21, 2010, from http://www.qrcode.es $/ ? \mathrm{p}=350$ \&language $=\mathrm{en}$

ISO (2010). ISO/IEC 18004:2006. Retrieved June 21, 2010, from http://www.iso.org/ iso /iso_catalogue/catalogue_tc/catalogue detail.htm?csnumber $=43655$

ITSC (2008). Section 3: QR Code. Synthesis Journal. Information Technology Standards Committee Singapore. Retrieved June 21, 2010, from http://www.itsc.org.sg /pdf/ synthesis08/Three_QR_Code.pdf

JISC (2010). JIS X 0510:2004. Retrieved May 15, 2010, from http://www.jisc.go.jp/app / pager?id=12766 (written in Japanese)

JISC (2005). Innovative Practice with e-Learning: a good practice guide to embedding mobile and wireless technologies into everyday practice, Bristol: Joint Information Services Committee.

Kukulska-Hulme, A., \& Traxler, J. (Eds) (2005). Mobile Learning: A Handbook for Educators and Trainers. London: Routledge.

Liu, T., Tan, T., \& Chu, Y. (2007). 2D Barcode and Augmented Reality Supported English Learning System. Proceeding of the 6th IEEE/ACIS International Conference on Computer and Information Science (pp 5-10). IEEE Computer Society.

Naismith, L., Lonsdale, P., Vavoula, G., \& Sharples, M. (2005). Literature Review in Mobile Technologies and Learning, NESTA Futurelab Series.

NWT (2010). The National Math Trail. Retrieved September 20, 2010, from http:// www.nationalmathtrail.org/

Osawa, N., Noda, K., Tsukagoshi, S., Noma, Y., Ando, A., Shinuya, T., \& Kondo, K. (2007). Outdoor Education Support System with Location Awareness Using RFID and Symbology Tags. Journal of Educational Multimedia and Hypermedia, 16(4), 411-428.
Pachler, N. (Ed.) (2010). Mobile Learning: Structures, Agency, Practices. NY: Springer Rizzo, S. (2009). QR-code Periodic Table of Elements. Retrieved May 15, 2010, from http://www.nerdnews.it/2009/03/17/qrcode-periodic-table-of-elements/

Sharples, M. (Ed.) (2007). Big Issues in Mobile Learning. LSRI, University of Nottingham

So, S. (2008). A Study on the Acceptance of Mobile Phones for Teaching and Learning with a group of Pre-service teachers in Hong Kong. Journal of Educational Technology Development and Exchange, 1(1), 81-92.

Susono, H., \& Shimomura, T. (2006). Using Mobile Phones and QR Codes for Formative Class Assessment, In A. Méndez-Vilas, A. Solano Martín, J.A. Mesa González and J. Mesa González(Eds), CurrentDevelopments in Technology-Assisted Education (Vol. 2) (pp 1006-1010). Badajoz, Spain: FORMATEX

江信宇(Chiang)、王淳、張雯珺、劉永偉和 陳俊廷 (2007): 利用QR code建置校園資 訊交流本台，《TANET2007臺灣網際網 路砶討會論文集》, 瀏覽日期: 21-6-2010, http://thesis.lib.nccu.edu.tw/cgi-bin/gs31/ test.cgi?o=dtest

黃天佑(Huang, T.)、林家正和許雅惠 (2008): 二維條碼行動學習系統之教學成效研究, 《TANET2008臺灣網際網路研討會論文 集》,瀏覽日期: 21-6-2010, http://thesis.lib. nccu.edu.tw/cgi-bin/gs31/test.cgi?o=dtest

冢瑞明 (Chao, R.) 、藍大勝、張佳楠和陳雍 宗 (2007): 以行動載具結合二維條碼與 數位學習本台建構無所不在的STS合作 學習環境, 《屏東育大學資訊科學應用期 刊》, 第 2 卷 2 期, 瀏覽日期: 21-6-2010, http://www.cs.npue.edu.tw/jour/vol2isu2. htm

陳熙玫 (Chen, H.)、謝金村和黃星瑋 (2008): 應用二維行動條碼於U-Learning 之研 究, The Conference on Ubiquitous Home (UHC2008), Taiwan. 


\section{Acknowledgement}

This paper is based on the experiment conducted by Miss Ching-yin Law for her final year project supervised by Dr. Simon So. The authors greatly appreciate the support of Ms. Wong Hang Luen and her school, Queen Elizabeth School Old Students' Association Primary School, and Mr. Ko Kin Sang and his school, Christian Alliance S Y Yeh Memorial Primary School.

\section{Contact the Authors}

Ching-yin Law

Hong Kong Institute of Education, HK

E-mail: s0604426@s.ied.edu.hk

Simon So, Ph.D.

Hong Kong Institute of Education, HK

E-mail: swwso@ied.edu.hk 